\title{
Effect of treatment with cimetidine for one year on gastrin cell and parietal cell function and sensitivity to cimetidine in patients with duodenal or gastric ulcers
}

\author{
H. P. M. FESTEN \\ M.D. \\ C. B. H. LAMERS \\ M.D. \\ A. TANGERMAN \\ Ph.D. \\ J. H. M. VAN TONGEREN \\ M.D.
}

Department of Medicine, Division of Gastroenterology, St Radboud Hospital, Nijmegen, The Netherlands

\begin{abstract}
Summary
Twenty-two duodenal and 16 gastric ulcer patients were treated with $\mathbf{4 0 0} \mathrm{mg}$ cimetidine twice daily for one year after their ulcers had healed. No change in gastric acid secretion was observed before and after treatment in 20 duodenal and 13 gastric ulcer patients. Similarly, the inhibitory effect of $200 \mathrm{mg}$ cimetidine on gastric acid secretion was unaltered in 11 duodenal and 6 gastric ulcer patients studied and cimetidine blood concentration were unchanged in 9 duodenal and 4 gastric ulcer patients after one year. In 7 duodenal and 6 gastric ulcer patients the serum gastrin response to a standard test meal before and after treatment was identical.
\end{abstract}

\section{Introduction}

Maintenance treatment with cimetidine in a low dose is effective in preventing duodenal ulcer relapse (Bodemar and Walan, 1978; Blackwood, Maudgal and Northfield, 1978; Gumand-Høyer et al., 1978; Burland et al., 1978; Gray et al., 1978; Hetzel et al., 1978). In the prevention of gastric ulcer relapse cimetidine seems equally effective (Machell et al., 1979; Birger Jensen et al., 1979). Treatment with cimetidine for short periods seems to be safe, but after-effects of such treatment on parietal and gastrin producing cells may become overt only during long-term treatment. Furthermore, it has to be demonstrated that inhibition of gastric acid secretion by cimetidine does not change with time. Some of these aspects have been studied in duodenal ulcer patients. (Hetzel et al., 1978; Forrest et al., 1979; Spence et al., 1978a, b; Sewing et al., 1978; Bodemar et al., 1979). In gastric ulcer patients, however, no studies of this kind have yet been done. This study was undertaken to assess the effect of one year's continuous treatment with cimetidine on gastrin-cell function (as determined by postprandial serum gastrin levels) and on parietal cell function (as assessed by basal and pentagastrin-stimulated gastric acid secretion) in duodenal and gastric ulcer patients. The inhibition of gastric acid secretion? by cimetidine was also studied, before and after one year's treatment.

Patients and methods

Thirty-eight peptic ulcer patients without prior $\overrightarrow{-}$ gastric surgery were studied, 22 of whom had å duodenal and 16 a gastric ulcer. One duodenalo ulcer and 7 gastric ulcer patients were females. The mean age in duodenal ulcer patients was $48-84 \cdot \overrightarrow{0}$ years and in gastric ulcer patients, $51 \pm 3$ years. 10 patients had endoscopically assessed healed ulceis. before the start of maintenance treatment. Treatmento with $400 \mathrm{mg}$ cimetidine after breakfast and $400 \mathrm{mg}$ at bedtime was continued for one year. To testo patient compliance, a qualitative check on cime- $\frac{\mathscr{Q}}{\mathbb{D}}$ tidine in a urine sample was performed at each bi-monthly follow-up visit. The detection of cime- $\overrightarrow{\overrightarrow{0}}$ tidine in the urine was performed by thin layer3 chromatography (Smith, Kline and French Laboratories, England; personal communication). Immediately before the start of cimetidine treatment, 을

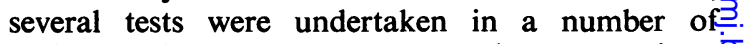
patients. These tests were repeated one year later 3 between 3 and 7 days after cimetidine had been. stopped. At repeat tests for gastric acid secretion $\frac{\text { }}{3}$ and serum gastrin, concomitant blood cimetidine concentrations were assessed: these were all below detection level $(<0.05 \mu \mathrm{g} / \mathrm{ml})$.

\section{Tests performed:}

Gastric analysis was done in 20 duodenal and 13N gastric ulcer patients. After an overnight fast, a gastric tube was positioned according to the method ${ }^{\infty}$ described by Hector (1968). Four 15-min basa secretory collections were aspirated and sub-c sequently 4 15-min samples were collected afteres? i.m. injection of $6 \mu \mathrm{g} / \mathrm{kg}$ pentagastrin. Peak acid output was calculated as the sum of the 2 consecutiveo highest 15 -min samples multiplied by 2 . Hydrogen 
ion concentration (mmol $\left.\mathrm{H}^{+} / \mathrm{l}\right)$ was determined by titration with $0 \cdot 1 \mathrm{~mol} \mathrm{NaOH}$ up to $\mathrm{pH} 7 \cdot 0$.

Gastric acid secretion after cimetidine was determined in 11 duodenal and 6 gastric ulcer patients.

One hour after the oral intake of $200 \mathrm{mg}$ cimetidine, gastric secretion was measured as described above. However, basal secretion was measured during 215 -min periods only. This $30-\mathrm{min}$ result was multiplied by 2 and expressed as $\mathrm{mmol} \mathrm{H}^{+} / \mathrm{hr}$.

Cimetidine blood concentrations were measured in 9 duodenal and 4 gastric ulcer patients. Venous blood samples were drawn 60, 90, 105 and $135 \mathrm{~min}$ after the oral intake of $200 \mathrm{mg}$ cimetidine during gastric analysis. Heparinized whole blood was stored at $-20^{\circ} \mathrm{C}$ and cimetidine concentrations were determined by high pressure liquid chromatography as described by Randolph et al., (1977). The minimal detectable blood concentration by this method was $0.05 \mu \mathrm{g} / \mathrm{ml}$. All samples were assessed in duplicate.

Serum gastrin levels were measured in 7 duodenal and 6 gastric ulcer patients. Levels were determined, fasting and 15, 30, 45, 60, 90 and $120 \mathrm{~min}$ after a standard test meal. The test meal consisted of one slice of white bread, $50 \mathrm{~g}$ cheese, one boiled egg and $200 \mathrm{ml}$ skimmed milk, containing in total: $30 \mathrm{~g}$ protein, $20 \mathrm{~g}$ fat and $24 \mathrm{~g}$ carbohydrate. The integrated gastrin response (IGR) was calculated by determining the area under the curve of the gastrin concentrations after subtraction of the basal concentration. Pre-treatment samples were stored at $-20^{\circ} \mathrm{C}$ and were analysed together with posttreatment samples in the same assay to avoid interassay variation. Serum gastrin concentrations were assessed by radio-immunoassay using a rabbit antiserum (Rehfeld, Stadil and Rubin, 1972; Lamers, 1976). This antiserum raised against human gastrin $I$, 2-17, co-valently coupled to bovine serum albumin, binds all known C-terminal gastrin components with an almost equimolar potency (Rehfeld et al., 1979). In 137 normal subjects the serum gastrin concentration was $39 \pm 15 \mathrm{pg} / \mathrm{ml}$ (mean \pm 1 s.d.; range $10-86 \mathrm{pg} / \mathrm{ml}$ ).

For statistical analyses Wilcoxon's Signed Rank test for matched pairs and Mann Whitney $U$ test were used. Data are presented as the mean +1 s.e.mean. Lack of significant differences on statistical analysis is signified by (n.s.).

\section{Results \\ Patient compliance}

No patient failed to attend any of the follow-up visits during maintenance treatment. Bi-monthly urine cimetidine checks were, with 14 exceptions $(6 \%)$ in different patients, all positive.
Gastric acid secretion and its inhibition by cimetidine

There was no difference between the pre- and post-treatment data neither in duodenal nor in gastric ulcer patients (Figs 1(a) and 1(b)).

\section{Blood cimetidine concentrations}

There was no difference between the data of the duodenal and the gastric ulcer patients studied and so they were pooled. The mean cimetidine blood level between 60 and $135 \mathrm{~min}$ after oral medication with $200 \mathrm{mg}$ before treatment was $0.83 \pm 0.08 \mu \mathrm{g} / \mathrm{ml}$ and after one year $0.88 \pm 0.08 \mu \mathrm{g} / \mathrm{ml}$ (n.s.). The mean peak blood concentrations were $1.05 \pm 0 \cdot 10$ and $1 \cdot 11 \pm 0 \cdot 10 \mu \mathrm{g} / \mathrm{ml}$ (n.s.) respectively.

\section{Serum gastrin}

In duodenal ulcer patients the fasting and mealstimulated serum gastrin concentrations before and after one year's treatment were not significantly different; the fasting concentrations being $42 \pm 5$ and $47 \pm 5 \mathrm{pg} / \mathrm{ml} \mathrm{(n.s.)} \mathrm{and} \mathrm{the} \mathrm{IGR} 5 \cdot 8 \pm 0 \cdot 8$ and $6 \cdot 1 \pm 1 \cdot 4$ $\mathrm{ng} / \mathrm{ml}$ at $120 \mathrm{~min}$ (n.s.) respectively. In gastric ulcer patients, the fasting serum gastrin concentration before treatment was $42 \pm 7 \mathrm{pg} / \mathrm{ml}$ and after therapy $58 \pm 11 \mathrm{pg} / \mathrm{ml}$ (n.s.). The IGRs were $6.4 \pm 1.2$ and $7 \cdot 0 \pm 1 \cdot 3 \mathrm{ng} / \mathrm{ml}$ at $120 \mathrm{~min}$ (n.s.) (Fig. 2) respectively.

\section{Discussion}

The present study shows that one year's treatment with cimetidine does not influence gastric acid secretion. Other investigators reported similar findings in duodenal ulcer patients (Bodemar and Walan, 1978; Forrest et al., 1979; Spence et al., 1978a). This study shows that gastric acid secretion in gastric ulcer patients is also unaltered. Whatever mechanism causes the relative hyposecretion of gastric acid in gastric ulcer patients, it was unchanged after one year's treatment with cimetidine while the ulcer remained healed. The basal and postprandial serum gastrin concentrations in duodenal and gastric ulcer patients were unaltered after one year's treatment with cimetidine. Other reports on serum gastrin in duodenal ulcer patients after the long-term use of cimetidine have been conflicting (Forrest et al., 1979; Spence et al., 1978b; Sewing et al., 1979). There are no other reports on serum gastrin in gastric ulcer patients after the long-term use of cimetidine.

It might be assumed that possible after-effects of long-term cimetidine treatment on gastrin cell function and on parietal cell function will become manifest earlier in gastric ulcer patients than in duodenal ulcer patients owing to the significantly lower gastric acid secretion after cimetidine in this condition (Festen, Lamers and van Tongeren, 1978). Such an effect, however, was not demonstrated in this study. 
Percentage inhibition

Fig. I(a) (20 duodenal ulcer patients)
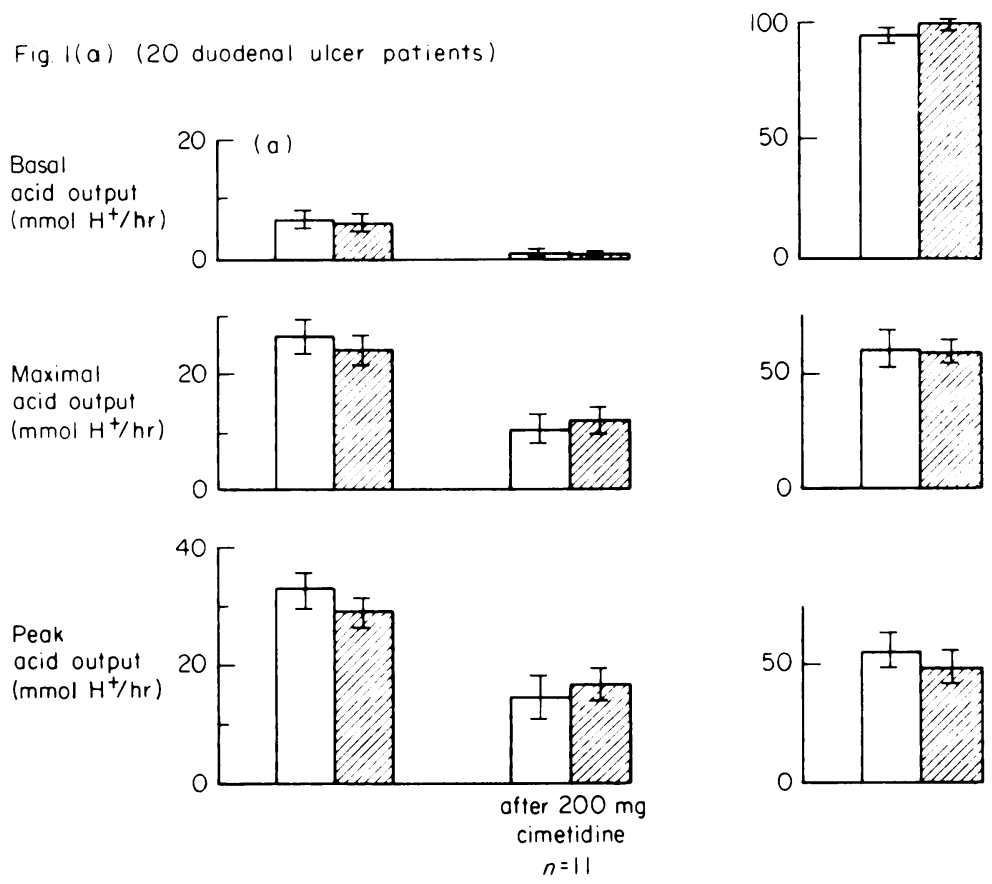

Fig. I(b) (13 gastric ulcer patients)

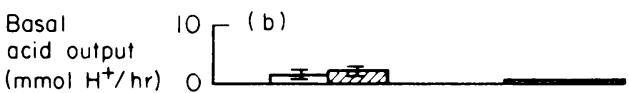

Percentage inhibition
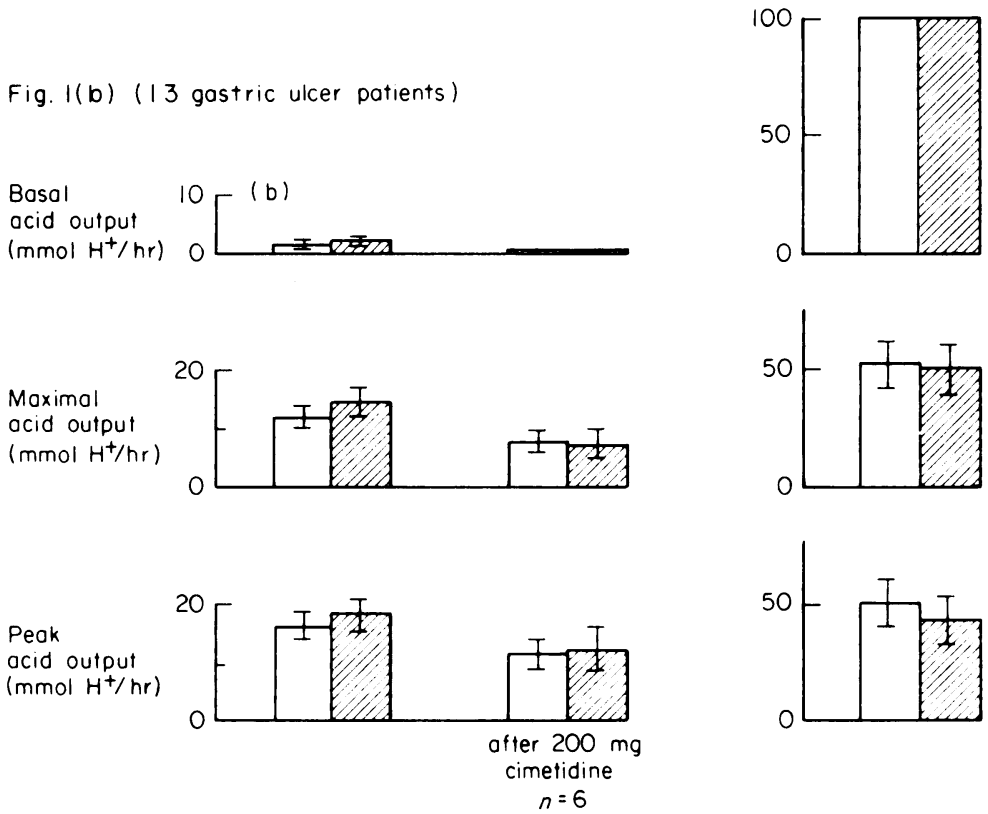

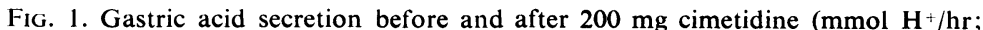
mean \pm s.e. mean) ${ }^{\ulcorner}$and resulting percentage inhibition (mean \pm s.e. mean) before $(\square)$ and after $(\mathbb{Z})$ ) one year's treatment with cimetidine. 
Cimetidine remained effective during one year's continuous treatment: blood concentrations of cimetidine and inhibition of gastric acid secretion were unchanged.

It is concluded that after one year's maintenance therapy with cimetidine in duodenal and gastric ulcer patients no rebound phenomena, or aftereffects on gastric acid secretion, or serum gastrin concentrations were observed. The acid inhibitory effect of cimetidine did not change.

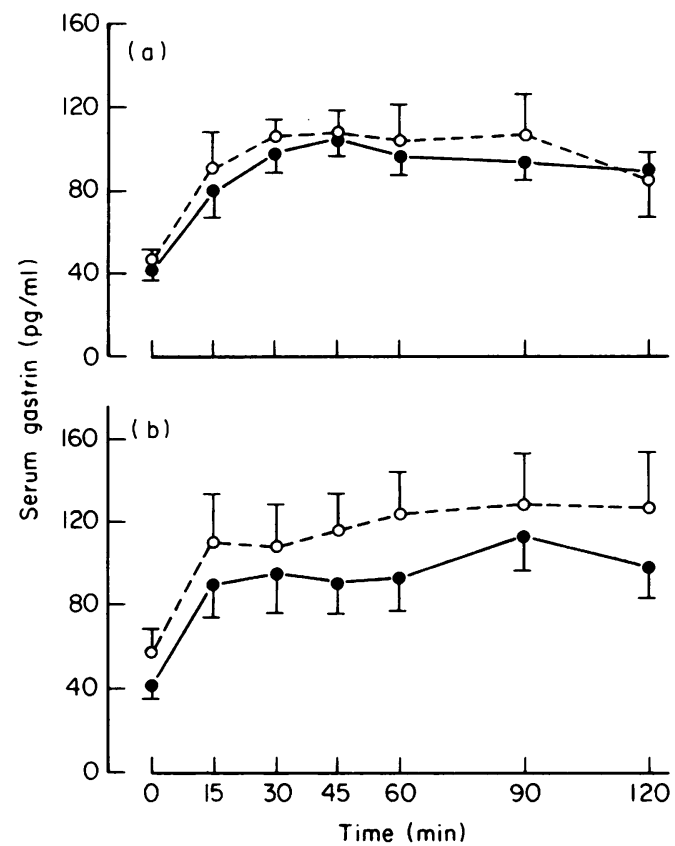

FIG. 2. Serum gastrin levels ( $\mathrm{pg} / \mathrm{ml}$; mean \pm s.e. mean) fasting and in response to a test meal before (-0) and after one year treatment $(\mathrm{O}---\mathrm{O})$ with cimetidine in (a) 7 duodenal and (b) 6 gastric ulcer patients.

\section{Acknowledgments}

The authors thank W. Roeffen for serum gastrin determinations and I. Jansen, A. Smals and L. Engels, medical students, for technical assistance.

Cimetidine was kindly supplied by Smith, Kline and French Laboratories.

\section{References}

Birger Jensen, K., Møllmann, K.M., Rahbek, I., Rask Madsen, J., RUNe, S.J. \& WUlfF, H.R. (1979) Prophylactic effect of cimetidine in gastric ulcer patients. Scandinavian Journal of Gastroenterology, 14, 175.

BlackWood, W.S., Maudgal, D.P. \& Northfield, T.C. (1978) Prevention by bedtime cimetidine of duodenal ulcer relapse. Lancet, $\mathbf{i}, 626$.

Bodemar, G. \& Walan, A. (1978) Maintenance treatment of recurrent peptic ulcer by cimetidine. Lancet, i, 403.

Bodemar, G. Norlander, B., Fransson, L. \& Walan, A. (1979) The absorption of cimetidine before and during maintenance treatment with cimetidine and the influence of a meal on the absorption of cimetidine. Studies in patients with peptic ulcer disease. British Journal of Clinical Pharmacology, 7, 23.

Burland, W.L., HaWkins, B.W., Horton, R.J. \& BERESFORD, J. (1978) The longer-term treatment of duodenal ulcer with cimetidine. In: Cimetidine: Proceedings of the Westminster Hospital Symposium 1978. (Ed by Wastell, C. \& Lance, P.), p. 66. Churchill-Livingstone, Edinburgh, London and New York.

Festen, H.P.M., LAMERS, C.B.H. \& VAN TONGeren, J.H.M. (1978) De onderdrukking van de maagzuurproductie door middel van cimetidine: resultaten van een dubbelblind onderzoek naar de betekenis van cimetidine voor de behandeling van peptische ulcera. Nederlands Tijdschrift voor Geneeskunde, 122, 862.

Forrest, J.A.H., FetTes, M.R., McLoughlin, G.P. \& HeAding, R.C. (1979) The effect of long-term cimetidine on gastric acid secretion, serum gastrin and gastric emptying. Gut, 20, 404.

Gray, G.R., Smith, I.S., Mackenzie, I. \& Gillespie, G. (1978) Long-term cimetidine in the management of severe duodenal ulcer dyspepsia. Gastroenterology, 74, 397.

Gumand-Høyer, E., Birger-Jensen, K., KraG, E., Rask Madsen, J., RahbeK, I., Rune, S.J. \& WulfF, H.R. (1978) Prophylactic effect of cimetidine in duodenal ulcer disease. British Medical Journal, 1, 1095.

Hector, R.M. (1968) Improved technique of gastric aspiration. Lancet, i, 15.

Hetzel, D.J., Hansky, J., Shearman, D.J.C., Korman, M.G., HeCKer, R., TAGgaRT, G.J., JACKSON, R. \& GABB, B.W. (1978) Cimetidine treatment of duodenal ulceration. Short-term clinical trial and maintenance study. Gastroenterology, 74, 389.

LAMERS, C.B.H.W. (1976) Some aspects of the ZollingerEllison syndrome and serum gastrin. Thesis, Nijmegen University.

Machell, R.J., Ciclitira, P.J., Farthing, M.J.G., Dick, A.P. \& HunTER, J.O. (1979) Cimetidine in the prevention of gastric ulcer replapse. Postgraduate Medical Journal, $55,393$.

RANDOLPH, W.C., Osborne, V.L., WALKenstein, S.S. \& INTOCCIA, A.P. (1977) High pressure liquid chromatographic analysis of cimetidine, an histamine $\mathbf{H}_{2}$-receptor antagonist, in blood and urine. Journal of Pharmaceutical Sciences, 66, 1148.

Rehfeld, J.F., Stadil, F. \& Rubin, B. (1972) Production and evaluation of antibodies for the radioimmunoassay of gastrin. Scandinavian Journal of Clinical and Laboratory Investigation, 30, 221.

Rehfeld, J.F., Stadil, F., Malmstrøm, J. \& Miyata, M. (1975) Gastrin heterogeneity in serum and tissue. In: Gastrointestinal Hormones. (Ed. by Thompson, J.C.), p. 43, University of Texas Press, Austin.

SeWIng, K.F., Hagie, L., IpPoliti, A.F., Isenberg, J.I., SAMLOFF, I.M. \& STuRDeVANT, R.A.L. (1978) Effect of one month treatment with cimetidine on gastric secretion and serum gastrin and pepsinogen levels. Gastroenterology, 74, 376.

Spence, R.W., Celestin, L.R., McCormick, D.A., OWens, C.J. \& OlIVER, J.M. (1978a) The effect of long-term treatment with cimetidine on gastric acid secretion and gastric responses in man. In: Cimetidine Proceedings of an International Symposium on Histamine $\mathrm{H}_{2}$-Receptor Antagonists. (Ed. by Creutzfeldt, W.), p. 116. Excerpta Medica, Amsterdam and Oxford.

SPENCE, R.W., MCCORMiCK, D.A., Oliver, J.M. \& Celestin, L.R. (1978b) The effect on serum gastrin of withdrawal of cimetidine after one year's treatment. In: Cimetidine: Proceedings of the Westminster Hospital Symposium, 1978. (Ed by Wastell, C. \& Lance, P.) p. 153. Churchill Livingstone, Edinburgh, London and New York. 